Em fluxo: entrevista com Dudude Herrmann

\title{
Patrícia Leal
}

\section{Dudude Herrmann}

\section{Resumo:}

$\mathrm{Na}$ presente entrevista propomos um fluxo de texto, escrito em doze dias, perguntas e reflexões fluídas, pouco a pouco, sobre a linguagem em improvisação, a possibilidade dramatúrgica em tempo real, a construção de imagens/textos sobre/com/através da Dança a partir de processos de criação das autoras.

\section{Palavras-chave:}

improvisação - fluxo - dramaturgia em tempo real - processos de criação estados corporais - percepção

Para o primeiro número de nossa tão aguardada revista Manzuá foram escolhidos os conceitos de "Fluxo e permeabilidade nas Artes Cênicas" como metáforas para a criação de uma plataforma que colabore para reflexões sobre teatro, dança, performance, cultura popular, tecnologias, metodologias e processos pedagógicos. Neste "estado de pesca de lagosta" resolvi contribuir com um Fluxo-entrevista com uma artista-performer-poeta-bailarina que muito admiro; Dudude Herrmann. A proposta é permear os fluxos de pensamentoimagem-estados do corpo-escrita, em um texto construído dia-a-dia, pergunta por pergunta, reflexão por reflexão, escuta-fala, leitura-escrita, imagemsentimento.... buscando o conteúdo não apenas pelo que está escrito, mas pelo modo como escolhemos escrever, fluir, teorizar a partir das pesquisas de nossos processos de criação.

Bom dia, Dudude?! Como estão as coisas por aí em Brumadinho?! 
Bom dia, Patrícia. Agora um pouco melhor, as chuvas finalmente chegaram e repõem a flora com esmero. Estamos, ano a ano, vivendo uma seca cada vez mais dramática e nos meses de Agosto, Setembro e Outubro é alarmante a questão de incêndios onde fauna, flora são atingidos, sem dúvida um espetáculo trágico, a falta de percepção sobre a questão ambiental em uma grande parcela dos seres humanos bípedes é uma Questão, mas seguimos e nesse momento aqui em Casa Branca chove e o verde resplandece e eu agradeço!!!

Aqui em Natal, sol entre nuvens, abafado. Sete horas da manhã, o corpo quente, lembro-me da sensação de fazer "Errática" (Funarte Klauss Vianna, 2013/14) na praça de Ribeirão Preto num calor incrível e numa invisibilidade nua para que as pessoas possam olhar para elas mesmas. Diferente de fazer aí em seu ateliê entre conversas e cheiro de tempero e jantar entre pares, amigos, atentos, e os ventos como parte do elenco levantando-me a saia, os papéis, as folhas, os cabelos. A partir de "Errática", uma obra que construí totalmente em fluxo, que fiz em espaços diferenciados como Museus, praças, teatros, descobri que para manter a improvisação fresca precisava ensaiar sempre outras coisas, coisas novas, imprevisibilidades, para poder manter o fluxo. E o delicioso paradoxo é que isso partiu sempre de memórias, atualizadas, ressignificadas, transformadas, esquecidas, criadas outras.

Num desses ensaios me propus a cantar várias músicas, enquanto dançava, e minha assistente me apontou que aquilo já era outro espetáculo. Assim nascia "Ponto Móvel" (FICC/Natal - 2015/16), meu processo de criação atual, aonde cantar, dançar, declamar, performar se horizontalizam com a interpretação do pianista Eduardo Taufic. Como está acontecendo e como nasceu "Sublime travessia"? Como acontece a linguagem da improvisação nesse trabalho? Existem permeabilidade em linguagens?

Bom saber que este trabalho Errática foi um deflagrador de ações para com um desejo de avançar e chegarmos, aqui agora, desse jeito assim. Viver é, certamente, um ponto atrás do outro e vamos aprendendo a "bordar"com esta linha continuada de um dia após o outro. "Sublime Travessia" nasceu de observações, contemplações, desejo de compartilhamento, falar deste país 
"gigante pela própria natureza, és belo, impávido colosso e o seu futuro espelha esta grandeza...", e muito, muito maltratado, desvalidado, usurpado. Senti em meu âmago a urgência de tratar e viver este assunto e confesso que tive um tempo largo e dilatado para construir, para deixar pousar os resíduos da observação atenta e continuada, pois o escritório de um artista fazedor está sempre aberto, não é mesmo?! Ganhei o Prêmio Klaus Vianna Funarte 2014 e, em 2016, finalmente recebemos o prêmio e, assim, dei início à fiscalização deixando que meu corpo-bússola escutasse as pistas e sinalizasse o caminho a ser tomado. Todo esse tempo de construção constrói uma dilatação interna, imaginativa, subjetiva que me guia, o que acho maravilhoso, intuição, instinto, percepção e go!

Todos os dias me pergunto ..o que pode vir a ser dança? E propositalmente não respondo, por que preciso ficar nesse território do não saber para assim seguir. Costumo dizer para as pessoas que estudam comigo: esqueçam de dança, esqueçam para que o corpo de cada um de vocês ensine vocês a fazerem e por aí vamos.

De uns tempos para cá tenho atuado no "modo solo". Com certeza, isso me traz liberdade de tomar decisões e encontrar "presentes" quando estou na ação da imagem, a questão de estar em "solo" para meu entender é sim mais uma estratégia para seguir fazendo do que meu desejo de estar em "solo", um modo de existir mais econômico nos tempos de ontem, hoje e quem sabe o Brasil sendo um país do Futuro possa algum dia tratar e cuidar deste campo sensível que é a arte, coisa tão essencial como formação sensível de uma cidade e fazermos trabalhos em GRUPOS!!!???. Voltando à questão: em "Sublime Travessia" tenho uma partitura sensível que quero e preciso atingir, mas o "como" farei isso é o risco e a disponibilidade do improvisador em si, que sabe que está a serviço da "VOZ" do trabalho, o que ele quer dizer, como quer dizer e assim a afinação acontece na conexão direta com tempo, lugar, espaço e ação. Não me preocupo com as linguagens separadas, a voz está colada no corpo e surgirá como um devir e prolongamento do gesto. Se uso de voz cantada, falada, performada, dançada está tudo junto, vieram todas de uma só fonte, o impulso "baquistródico" oriundo do desejo, necessidade vital, urgência 
de um artista que atua no campo da expressão, sendo assim o corpo da imagem é porosa, transitória, permeável todo o justo tempo do acontecimento.

Por que eu danço!!! Nossa... me lembrei de uma vez especialíssima, em que respondi isso a um amigo artista-cineasta-poeta-músico, Carito Cavalcanti, e do poema que fiz e acabou em off como trilha sonora de um de seus filmes. Respondi assim e, ainda, é uma verdade para mim:

"Dançar é como sopro de vida

inteiro, breve, leve...

Dançar é como Shiva,

move, transforma, alucina.

É um instante em sua retina,

mas eterno na memória

de cada uma de suas vísceras.

O que sinto quando danço?

Me sinto em casa

É como se eu estivesse fora e então descobrisse

Agora SOU

Dançar me aproxima do ser

porque quando sinto meu corpo enquanto danço

fluo vida em intensidades, sutilezas... 
A natureza da dança é mover

Natal combina muito com Dança com seus ventos e dunas

são de uma mesma natureza,

daquilo que só existe uma vez,

mas é eterno na sensação de quem presencia.

Dançar me trouxe tudo

o corpo, a vida, a voz

o amor, o filho..."

Ufa! É um alívio sentir alguém integrado!!! O artista é inteiro e cumpre, a meu ver, as exigências de sua obra. Você chamou de imagem, né, Dudude, hummmm... quero saber sobre isso, você compõe uma imagem?!

Imagens estão em movimento todo o tempo, componho, descomponho, recomponho em um continuado vir a ser. Dança é uma coisa que nunca está parada no tempo, ela segue e com ela somos levados, a dança atravessa corpos e no exato momento de seu acontecimento o corpo é atravessado por ela, imagens nos visitam enquanto estamos movendo dança e por aí seguimos...

Como acontece essa sensação?

Sinceramente, não consigo muito responder tal questão sem me deixar em devaneios, sensação via sentidos, perceptos, afetos produzem talvez uma 
imagem dançada, ou uma dança me traz uma determinada imagem, que registro via sensação, talvez desencape "algo" que pode estar no espaço.

E frua sobre detalhes sobre essa construção de linguagem da improvisação no seu corpo.

Meu corpo é um corpo passagem, transitória, atravessada, meu material de processar e publicar no espaço, um espaço veloz, dobrável, flexível, a sensação de ser mais um no espaço permanece...

Que potências você tem no corpo?

Não sei, e não posso e nem quero saber, tenho a "fome" "o desejo" "a curiosidade" de perseguir "alguma coisa" que sinceramente não sei, a improvisação acontece no justo tempo real do acontecimento, E aí está sua preciosidade, isso sim me interessa. Presente, presente, presente!

\section{Que estados?}

Estados de Dança, uso esta conjunção de palavras que se correlacionam com o momento já, e não tenho certeza alguma, mas prezo pela disponibilidade, pela simplicidade e juntos audiência e improvisadores possam em um determinado tempo se reconhecerem em estados onde a dança aparece junto!

E como você vai concretizando-os, concretizando-as em seu corpo em diálogo com o espaço, com as pessoas que assistem, com o que você quer expressar?

Não acontecem em meu corpo, acontece JUNTO!, Os acordos vão se dando e cabe ao improvisador cortar, recortar e administrar aquilo que se apresenta no espaço, uma somatória de eventos, dispares, fragmentados, para mim, agora, o improvisador precisa estar "vazio" para que ele possa estar a serviço de algo maior do que ele, a ação se faz junto.

Me dê um exemplo-percepção de uma memória sua em uma apresentação. 
A perseguição de um improvisador é sim estar presente, inteiro, vivo no momento desta aparição dentro ser tempo ser espaço, assim ele se transformará em imagens que talvez possam remeter a possíveis memórias de futuro, memórias de Humano.

Adoro metalinguagem, então como podemos também aqui, nesta linguagem escrita, teorizando sobre dança, nos aproximar da linguagem que buscamos em improvisação?! Foi assim que escrevi "Em fluxo", meu último livro.

Sinceramente não sei, só sei que você se revela em mil fragmentos seus modos de mover, de olhar, de administrar as coisas do mundo, estão inseridos na forma que escreve, pensa, ama, vê e trata o mundo de dentro de fora, há uma coisa que nunca se altera desde de sua concepção até os últimos tempos de nossa existência sobre a terra, está registrada em suas células, seu DNA, e isso é maravilhoso, não queira tanto, porque podemos perder, mas por um outro prisma, perder é necessário , perder = achar são sinônimos e opostos em um lugar de composição em tempo real, uma linguagem cheia de paradoxos, de incertezas, de impermanências, como a vida!

Recordando sua linda escrita da resposta anterior "Viver é certamente um ponto atrás do outro", Ihe deixo com meu processo. Ponto Móvel, meu pontovida atual:

“Um ponto

dois pontos

reticências...

Um foco

Nó na garganta

Desfeito

E ponto 
fruto, maduro, seguro, escuro

Exclama!

Reta ponto

Espanto

Reclama sua parte

ponto e vírgula

em arte

insígnia

emblema

uma marca

de nascença

uma pinta

ponto

Um único momento de encontro

Um, que concentra toda a espera

toda, inteira

inebriada,

enevoada, 
alarmada,

febril e sã,

(e ainda)

num infinito ser

. ponto"

Seguimos nosso bordado, nossa colcha, nosso fazer, nosso encontrar e desencontrar enquanto aprendemos e desaprendemos pela vida afora

Corpos porosos e desejosos de se aventurar...

Uma imagem:

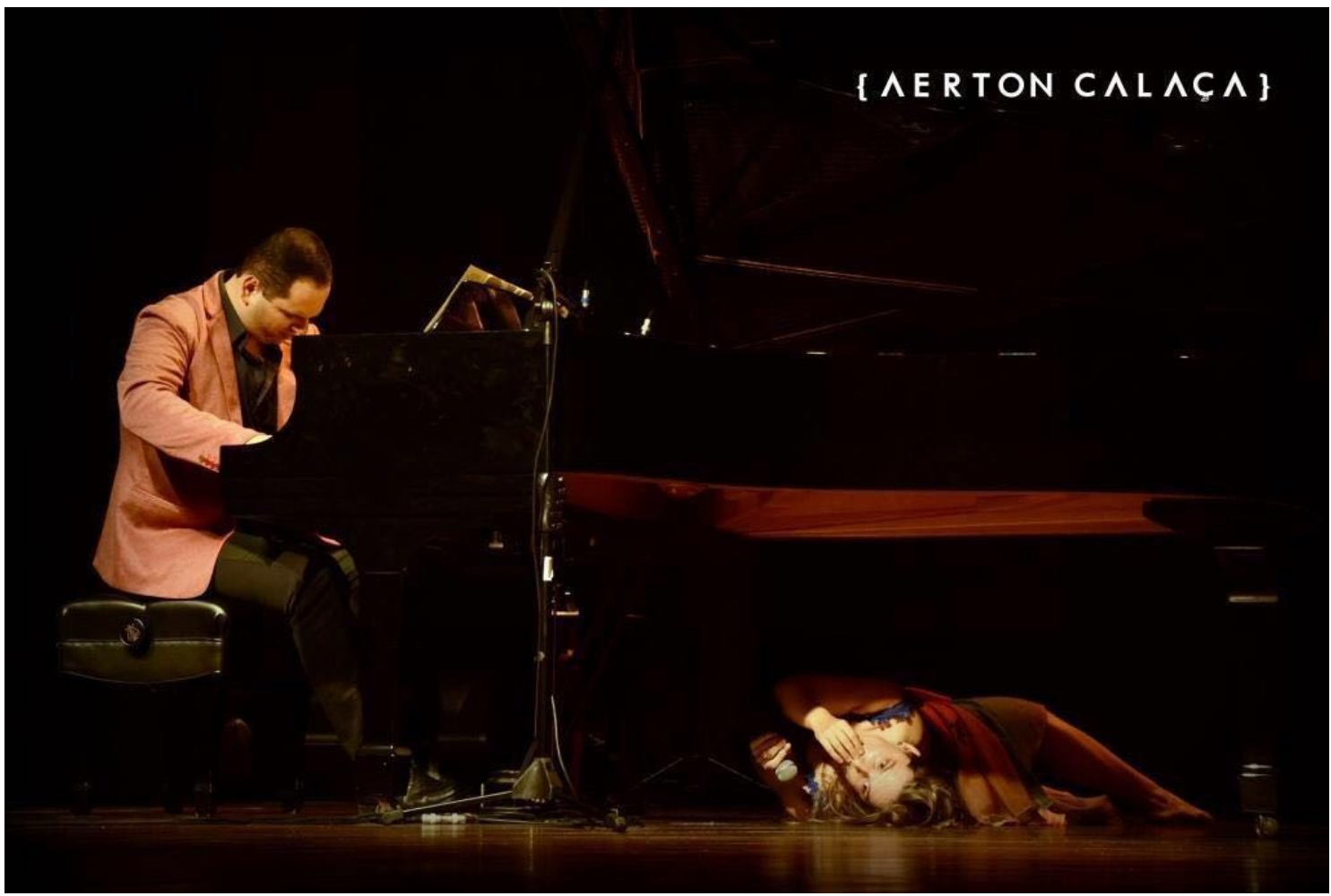

Imagem 01: "Ponto Móvel" (foto: Aerton Calaça).

Outra: 


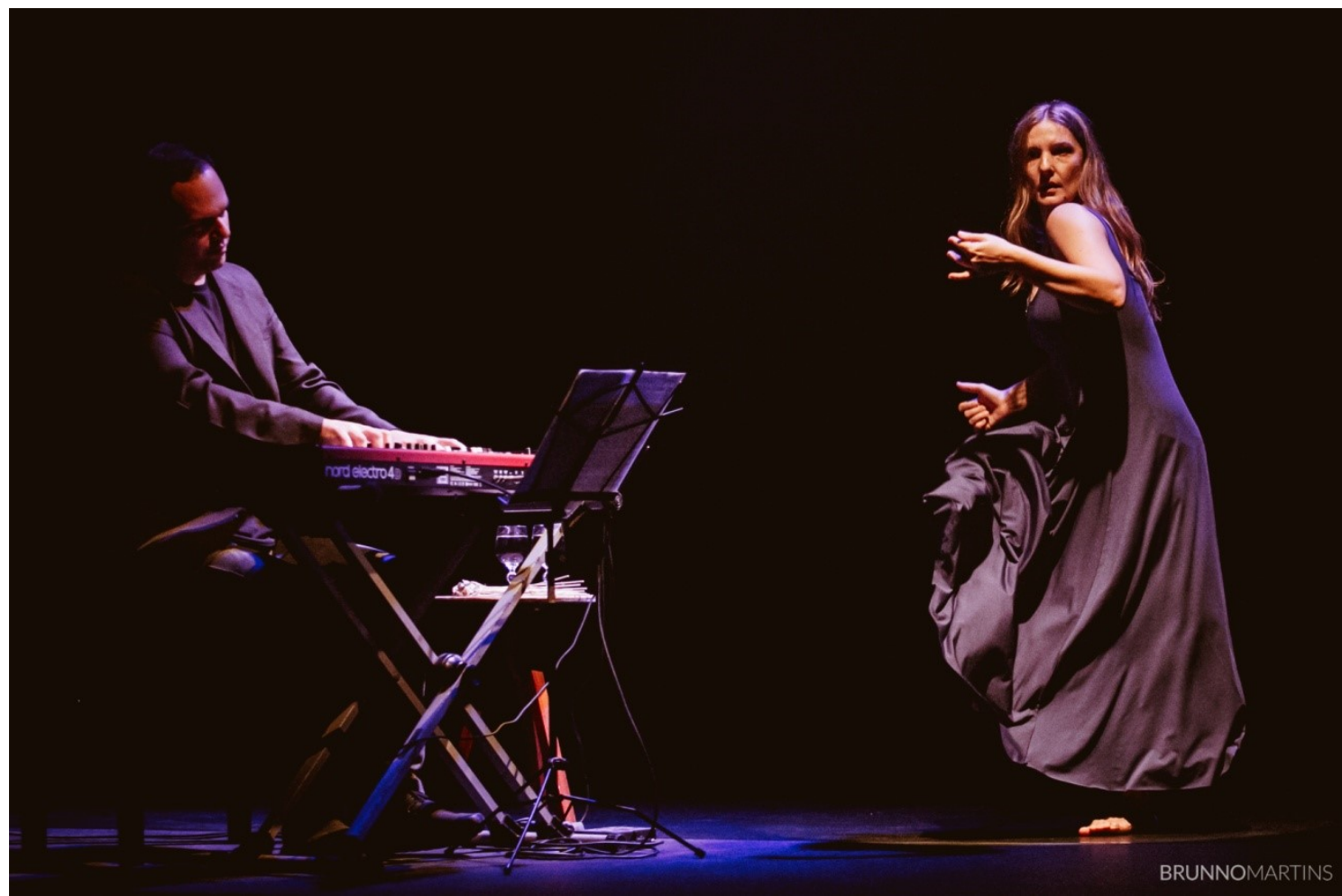

Imagem 02: "Ponto Móvel" (foto: Bruno Martins)

Presente, presente, presente... O que buscamos em imagem, em linguagem, em criação, em presença, se concretiza diferentemente na apreciação do outro. O olhar do outro sempre me espanta e é um presente na continua alimentação das criações que vivo. Em alguns olhares, me reconheço, em outros não, mas percebo a potência daquilo que é no momento da cena. Você poderia compartilhar conosco, Dudude, algumas imagens-espanto de seus trabalhos e como você percebe esse olhar do outro em relação à dança que te move?!! 


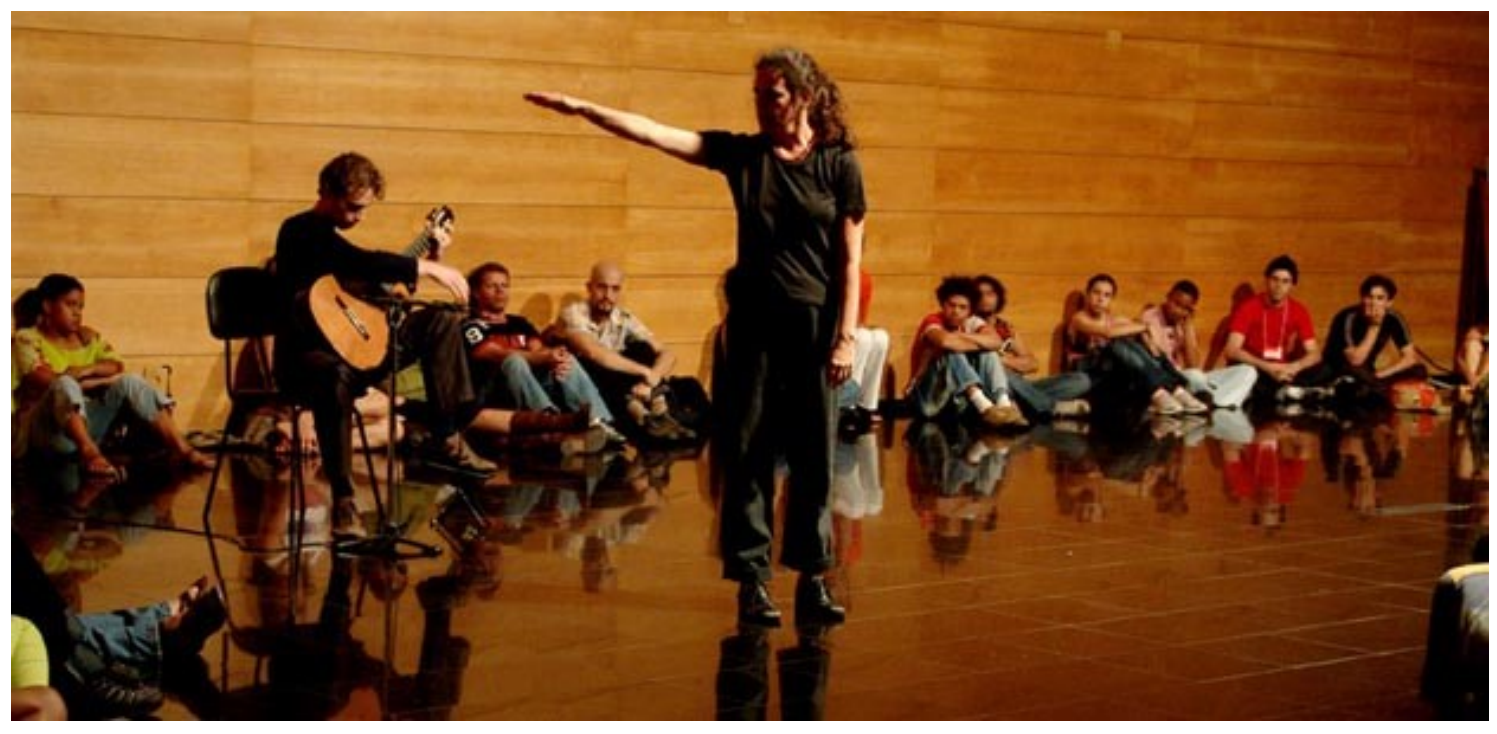

Imagem 03: Ipatinga eu e Frederico Herrmann; " As voltas com o dançar"

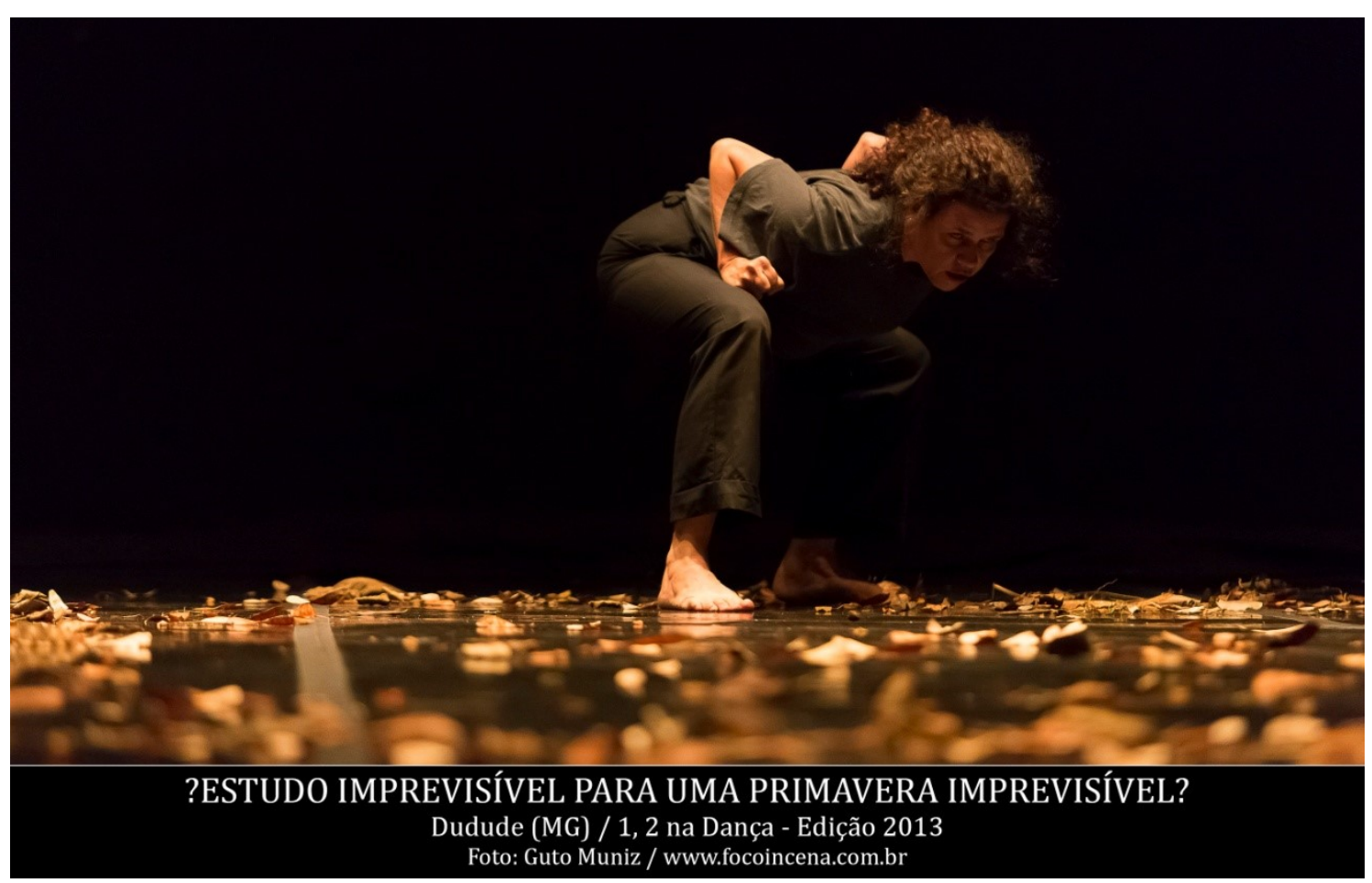

Imagem 04: "Estudo Imprevisível para uma primavera imprevisível" (foto: Guto Muniz). 


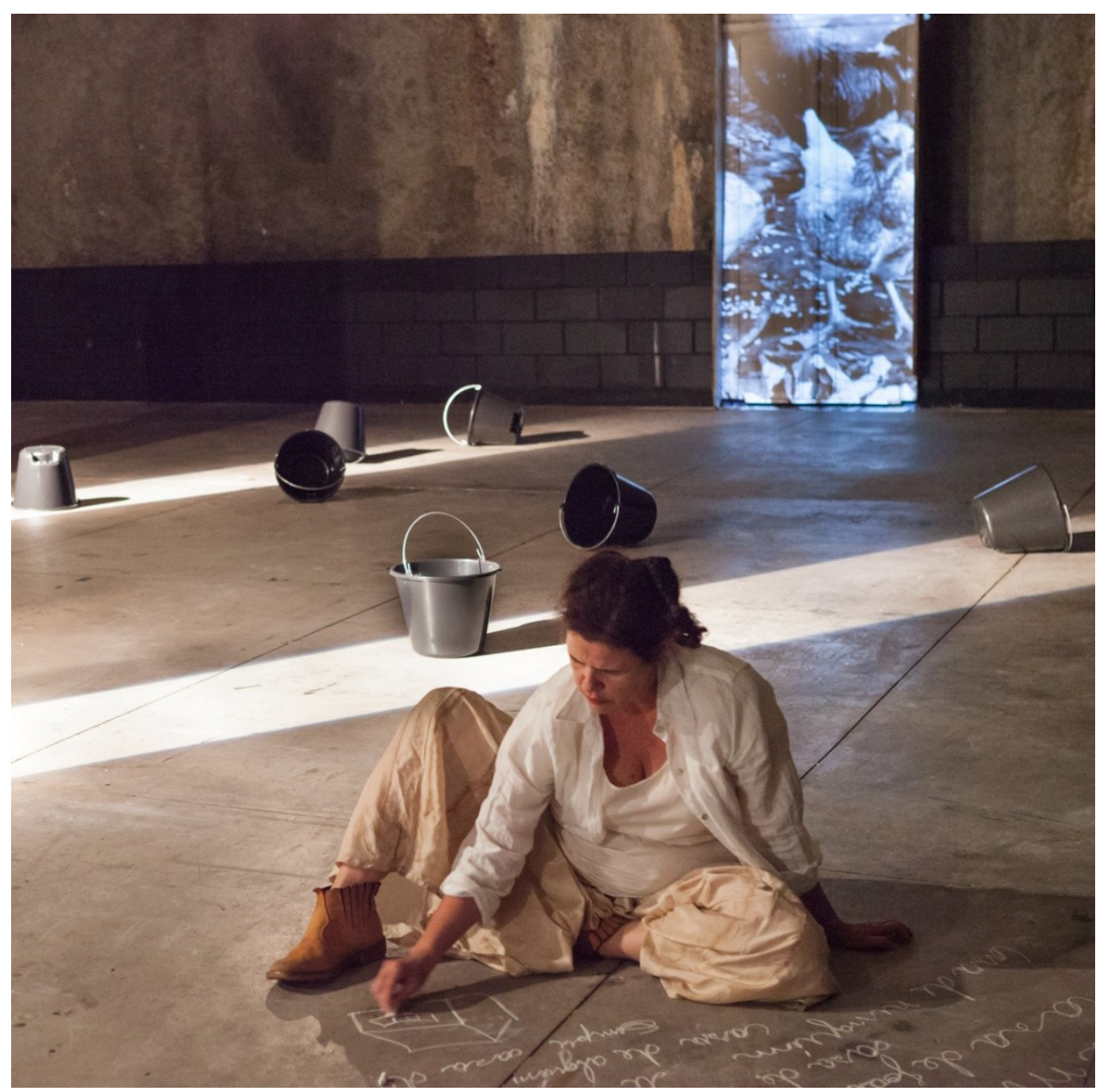

Imagem 05: "Casa" (foto: Sandro Miano), trabalho constituído por três solos inspirados na imagem da Casa, minha função era me deixar escrever e me deixar mover nutrida pelo espaço e imagem de um galinheiro de minha casa e um pianista e go.... 


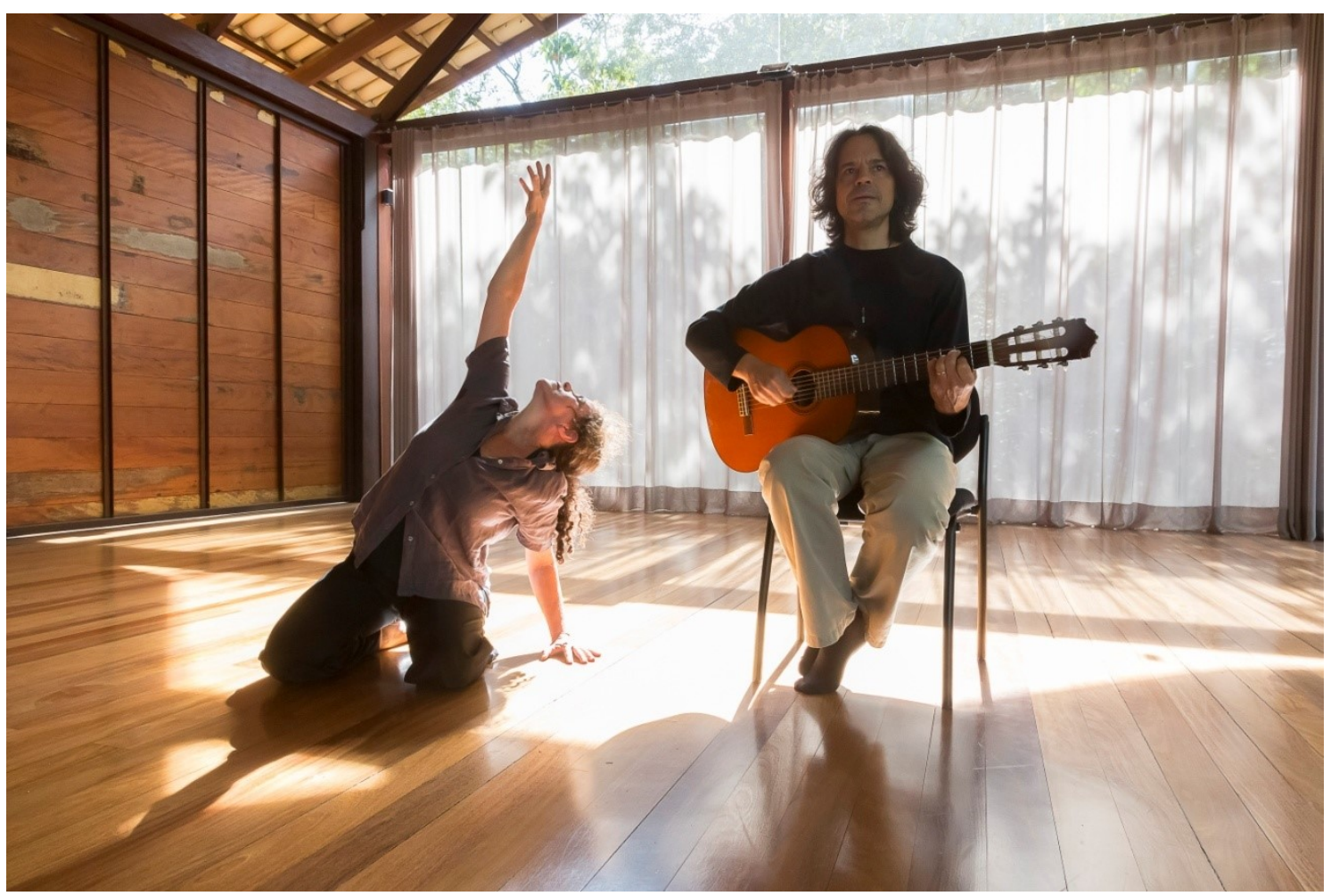

Imagem 06: Eu e Frederico Herrmann.

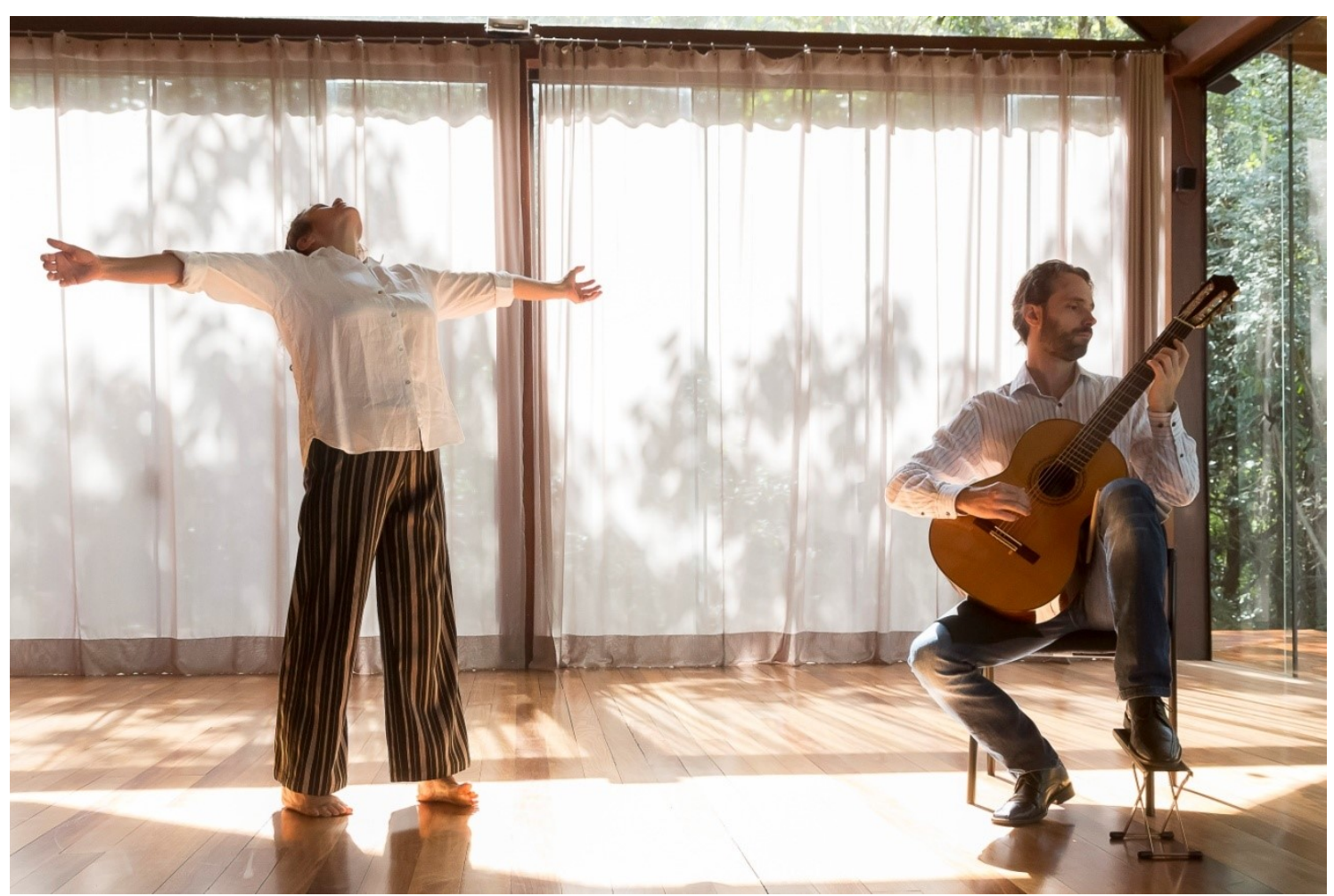

Imagem 07: Eu e Renato Motha. Violonistas com quem mantenho uma parceria continuada. 


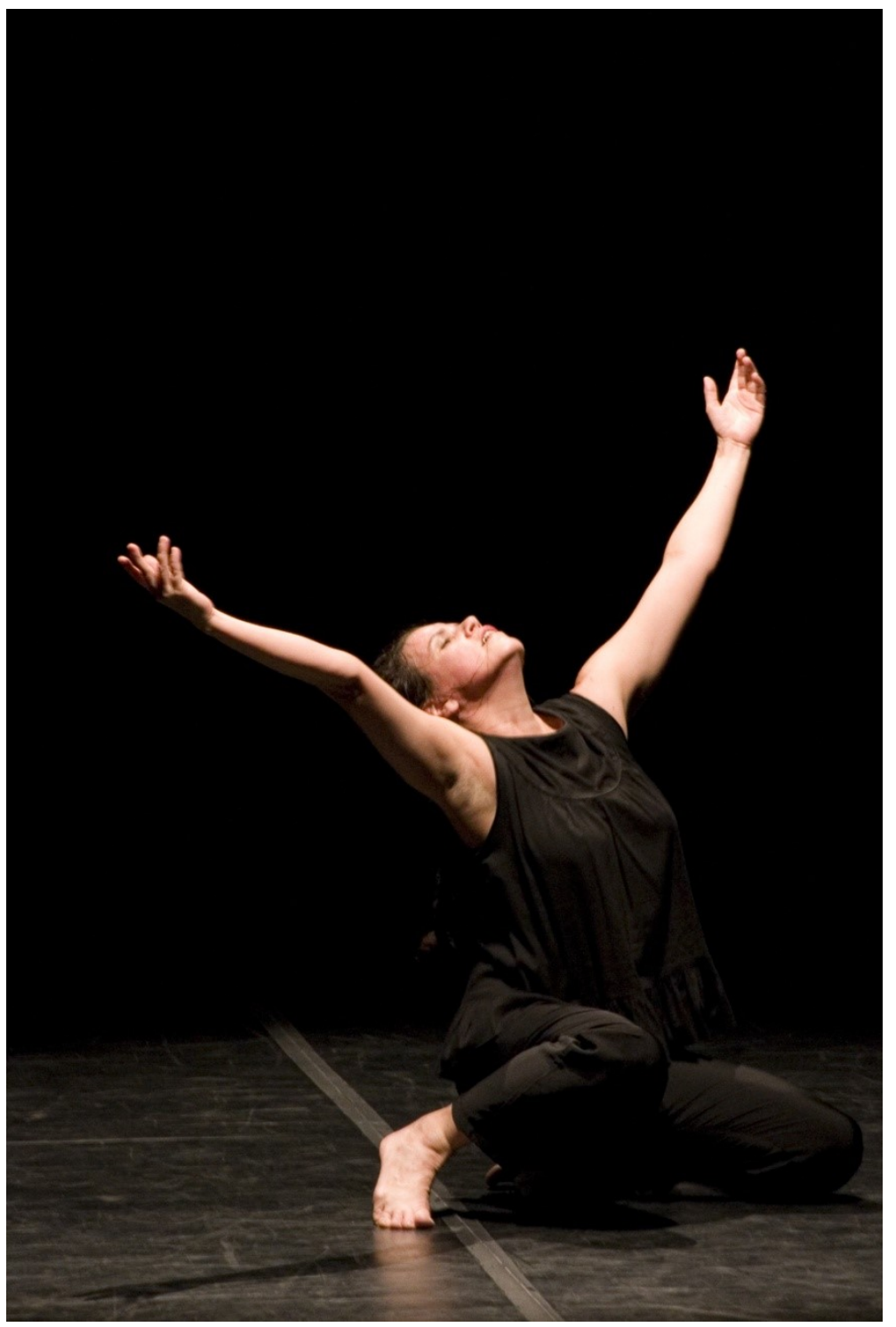

Imagem 08: "Pedaço de uma Lembrança"; trabalho em que revisito um lugar que considero ser meu primeiro trabalho improvisacional em 1976 e quando me apresento zero 'in my body' deixando que ele acesse a memória gravada e grafada nas células.

O que me move?

Quem seria o outro se não eu mesma?

O outro me é estranho, mas quando olho o outro ele também me olha como o outro e assim vamos...

Não está em mim, somente, mas está em nós, nos entre espaços, não sou eu que movo, todo o espaço se move e assim juntos e separados capturamos o 
que este conjunto que podemos nomear de espaço demanda; quando estou em processo improvisacional capturo, sou capturado, limpo, sujo, esvazio, desenho o que a percepção sensível me orienta a fazer.

Pausas dissonantes são importantes, o espaço e tudo que nele está fala! Tudo é importante, agir nos entre espaços, dilatar as pupilas, não se pre-ocupar antes do sucedido, se deixar ocupar e desocupar todo o tempo, e por incrível que possa parecer, o "eu" é o que menos importa.

Quando estamos na ação de desenhar, criar espaços possíveis de persuasão, fazemos juntos com todos que ali se encontram, sendo tanto animados quanto inanimados, quando estamos em grupo de improvisadores precisamos manter acordos onde a liberdade se faz necessária e a confiança de podermos usufruir daquilo que pode vir a ser mergulho em potência, se há acordos, afinidades existe também cumplicidade, jogo, atrevimento, curiosidade e podemos "talvez " entrar em espaços impossíveis onde só o corpo sensível vê e lê o que se passa, uma sensação quântica, certamente. Acredito que o improvisador persegue o desaparecimento de si, ele não está preocupado consigo mesmo, ele pertence a ação, está a serviço desta conjunção de eventos que podem ter duração de centésimos de segundos, por isso seu corpo busca a percepção da escuta quântica, desse mover fragmentado em mil possíveis oportunidades. O fim sempre chega e quando chegar lá estará ele novamente parado, visível e inteiro por chegar na superfície humana de existir.

Esta é uma imagem-espanto, que poucas e raras vezes tive o privilégio de fazer parte, de ser mais um, e a persigo na simplicidade, no desapego, e no humano torto que somos todos!

$\mathrm{AH}$ ! Preciso de mais um dia ou dois para absorver e voltar a perguntar dessa sensação quântica, do eu, de si, do fim... ou não mais perguntar, a sensação basta. Para mim, a improvisação é uma ampliação da consciência de si e do mundo e uma quase dissolução do ego, ou melhor, um acordo feito com o ego para que o si/o ser possa reinar. Em improvisação, mesmo com alguns roteiros, músicas pré-definidas ou pequenas estruturas, quanto mais consciente da ação do corpo, das tensões, fluxos, dos espaços, da relação com o outro, da 
temperatura, da luz... estou, no momento da cena, mais integrada ao todo e mais desconectada a uma identidade nominal me sinto. Contudo, nesses momentos de integração à ação do momento da cena é que me sinto mais viva. A sensação de conexão consigo e com o todo me parecem potências do Ser.

Sensação quântica, em improvisação abordamos muito as questões de intensidade, duração de imagens, falência das imagens, frequência, decadências, modulações, territórios macros e micros, povoações que se apresentam no instante, acordos, velocidades, potências , desaparecimentos, aparições, espaço, tempo e alçamos vôos que, para todo improvisador, ele sabe que o FIM sempre chega e ele precisa estar inteiro e atento para poder surfar em ondas, quando de fato estamos, nossa perseguição é estar no presente para que ele seja eterno e, assim sendo, será inesquecível para todos que ali se encontram, capturamos a imagem junto e, certamente, esta sensação quântica estará interligada entre todos os viventes. O espaço se torna sujeito da ação e todos e tudo que ali estão, são interdependentes deste acontecimento. A velocidade ganha graus de uma magnitude impressionante, veloz, improvisação é uma linguagem intelectual, precisamos ter repertório, ter um compêndio treinado de saídas e entradas, de construção e desconstrução, não está em mim, está nas somatórias dos eventos e nosso serviço é como tomar para si e fazer junto de tudo aquilo que se apresenta junto! Mais uma vez, ressalto a Improvisação atada à filosofia, à vida, à arte, e esse mistério instigante que nos faz seguir, seguir querendo profundamente se deixar "ESPANTAR" e adentrar em espaços possíveis, para tanto, imaginação, curiosidade são quesitos fundamentais para este SER.

Neste momento e, pela sensação que suas palavras me trazem de conforto em conjunto com às lindas imagens, queria perguntar sobre seu ateliê e sobre seu novo evento "No sofá com Dudude". Como foi essa escolha em ter um local de trabalho em casa, perto da natureza, envolto a tanto afeto e carinho?! Como essa escolha influencia e/ou determina a qualidade de seus trabalhos? De onde vem essa necessidade de agregar pessoas em casa para a produção artística?! E como foi a criação desse projeto do sofá, da conversa, da nutrição, 
com os quais muito me identifico e, de alguma forma, entro em ressonância nesse nosso diálogo.

Comecei em dança por acaso, e minha vida vai se apresentando assim, não programei muito quero ser, quero isto etc. (rsrsrs). Em 2007 estava em meu Estúdio, em um dia qualquer dando as aulas que sempre dei e olhei para os lados, para os estudantes que ali se encontravam, fui visitada de uma angústia, fazia já um tempo que o Estúdio não me dava o sustento necessário, então não esperei, chamei todos aqueles poucos que ali se encontravam e disse que a partir daquele dia não daria mais aulas, estava realmente exausta, desanimada e sem nada para compartilhar, êta país difícil este de se trabalhar com a matéria da arte. Fiz o mesmo com a Benvinda Cia de Dança, companhia que geri por dezesseis anos em uma espécie de furor desesperado. Sim, é dramático mesmo!!!

Assim fiz e cai em um "buraco", quebrei meu pé, fiquei um pouco sem lugar, tempo passou, eu e meu então companheiro (hoje não mais) resolvemos comprar uma casa na roça, (rsrsrs) que roça!! E então um dia, ele chegou para mim e disse: que tal construirmos um espaço para você ensaiar seus trabalhos? Eu disse: será?! Ele disse:sim.

Iniciei o trabalho, chamei dois arquitetos bacanas e pedimos a eles para fazerem o projeto, naquele momento o campo estava aberto, e o produto saiu melhor do que a encomenda, parecia que já estava escrito da necessidade desse Espaço se constituir como é.

E assim e 2010 surgiu o Atelier com uma missão de fazer dali um espaço fraterno, gerador e aglutinador de pessoas, artistas da cena viva e é o que venho fazendo, sem nenhuma viabilização por parte de governos, é duro, mas a Liberdade QUE TENHO NÃO TEM PREÇO!

Sempre gostei de empreender ações que me interessam, uma estratégia de sobrevivência aqui em meu país, tenho desejos de fuga continuadamente, mas SIGO! 
Partilhar, compartilhar, saber do outro, avançar, experimentar, inquietar, provar, provocar e mais outras tantas coisas estão a pauta diária de meu fazer.

Portanto DUDUDE ATELIER lugar de fortalecimento de Comunidade sensível, de travar relações, de saber do outro e por aí vamos sempre na porosidade, no atravessamento , e na impermanência deste caminhar em arte e na vida!

Em contrapartida a tudo isso surge o desejo de NO SOFÁ COM DUDUDE, que foi acolhido pela CASAMANGA aqui em BH na pessoa de Thembi Rosa, o No Sofá ....quer saber do outro, que é seu colega, saber sobre seus modos de existir, seus desejos frustrados, sua inquietação e etc. e tal e, assim, gentilmente, nos aproximamos e quebrarmos este lugar desvalido da competição, da inveja, do reclame, sabendo que ter colega é um modo de sobrevivência, na sensação de "não estamos sozinhos", neste ofício precisamos ter colegas para juntos ganharmos respaldo coragem e valentia ainda mais nos tempos de carestia que imperam nesses dias... Se quiser dê uma olhada no FACE CASAMANGA NO SOFÁ COM DUDUDE, incrivel como este evento está sendo bem recebido e meu desejo e vontade é realizar SOFÁS por todo o território nacional. As coisas que invento emergem na superfície e como uma ordem torna-se URGENTE sua fiscalização!

Para caminharmos para o fim, Dudude, queria que você compartilhasse algumas referências com as quais se sente em casa, para que os leitores possam seguir nossos rastros em suas pesquisas em busca da linguagem e dramaturgias possíveis da improvisação e composições em tempo real. A partir de nosso fluxo-entrevista posso citar autores com os quais venho encontrando diálogos possíveis como Damásio, Laban, Jung, Izquierdo, Cremezi, Fortin, entre outros. Também citaria alguns compositores que me influenciam mais em ". Ponto Móvel" como Luiz Tatit, Itamar Assumpção, Chico Buarque, Arrigo Barnabé. Algumas cantoras como Adriana Calcanhoto, Bebel Gilberto, Mônica Salmaso, Ná Ozzeti e, claro, em dança, sempre Pina.

Patrícia, pessoa linda, amorosa, romântica e também desejosa de bons encontros que possam nos deslocar do espaço que ocupamos na monotonia dos dias seguidos, sim, somos inquietos e esta inquietação nos provoca sair 
desses lugares de quando em vez. Desarrumar, des-aprontar, desviar, e fazer tudo de novo, mais uma vez, querendo descobrir, achar a N O V I D A D viver ali, mesmo que sejam segundos infinitesimais de aparição na potência quântica de possibilidade onde alegria, sensações plenas de vida, de vôos possam se instalar dentro!! Perseguiremos ad infinitum enquanto estivermos $\mathrm{V}$ I V O S!! Arejados e conectados nas ações linkadas na vida $\mathrm{X}$ arte, no corpo mundo x mundo corpo e assim caminhamos como assim dançamos, estamos juntos!

Inspirações estão quando estamos, o que pode me servir de bússola? Não só escritos, obras de arte, mas um monte coisas que atravessam um corpo já atravessado. Imagens das ondas do mar chegando e saindo de uma praia qualquer, me inspiram, seu cheiro, sua música, seu movimento podem, sim, me contar histórias de mundo e me trazerem filosofias profundas sobre arte, existência, etc. Vacas no pasto também, cheiro de café, danças de crianças soltas e movidas pela alegria, passarinhos pousados no fio, árvores no meio do mato, rios secos, limpos, caudalosos, sujos, tristes, notícias de jornais impressos, imagens das mais variadas, além de artistas que afinam com você, são muitos, como Simone Fortie, Lisa Nelson., Steve Paxton, Klaus Vianna, Katie Duck, Isadora Duncan, poetas dos mais variados como Manuel Bandeira, Baudelaire, Marcel Proust, Roberto Cohen e, muitos outros, tantos, que ainda nem conheci, mas sei que estão por aí, sinto pelo vento que não estamos sozinhos, somos poucos, mas estamos por toda a parte!

\section{Algumas palavras:}

\section{liberdade}

fluxo 
imagem

sentimento

improvisação afeto

percepção

ser

sentidos

outro

eu

tempo

continuidade

arte

...assimvamosdançandoavidaquenospermeiaemmeioaocaosaventaniaquetrazel evanoticiasquecirculamoplanetaterraescutoavoznaestradaventoouçoatrásdapor tameucoraçãodisparadojánãoqueroparardançoascançõesdeoutrostudojuntomin hascelulaspedemumcopodaguafontesdevariasnascentesetodooinstanteavidaval equandoaalmanãoépequenaequandoemnóssabemosquetemosasasdaimaginaç ão 